\title{
Analisis Penerapan Cleanliness, Health, Safety and Environmental Sustainability di Kawasan Wisata Kuliner Pasar Lama Tangerang
}

\author{
Febryola Indra
}

\section{Tourism Faculty, Pelita Harapan University, Jakarta Indonesia}

febryola.indra@uph.edu

\begin{abstract}
ABSTRAK
Kebijakan Cleanliness, Health, Safety, dan Environmental Sustainability (CHSE) ini dibagi berdasarkan panduan umum dan khusus yang menjadi syarat pengaplikasian pada rumah makan yang kemudian dilanjutkan dengan uji verifikasi oleh Kementerian Pariwisata dan Ekonomi Kreatif dan Lembaga Sertifikasi dari Indonesia Sustainable Tourism Certification (ISTC) baik oleh Global Sustainable Tourism Council (GSTC) atau Komite Akreditasi Nasional (KAN) untuk memperoleh legalitas rumah makan dapat beroperasi selama kondisi pandemi dengan adanya bukti labelling/sertifikasi. Adapun tujuan dari penelitian ini adalah untuk menganalisis penerapan cleanliness, health, safety dan environmental sustainability di Kawasan Wisata Kuliner Pasar Lama Tangerang. Jenis penelitian yang tim peneliti gunakan dalam penelitian ini adalah penelitian deskriptif kualitatif. Berdasarkan hasil penelitian dan pembahasan pada bab sebelumnya dapat ditarik beberapa kesimpulan guna menjawab rumusan masalah. Beberapa kesimpulan tersebut terdiri dari :Sebagian besar pedagang yang berjualan di Wisata Kuliner Pasar Lama sudah memahami konsep dari penerapan CHSE yang dianjurkan pemerintah, para pedagang yang berjualan di Wisata Kuliner Pasar Lama dapat memahami, menyatakan pengetahuannya serta menjalankannya mengenai penerapan cleanliness atau kebersihan, para pedagang yang berjualan di Wisata Kuliner Pasar Lama dapat memahami, menyatakan pengetahuannya serta menjalankannya mengenai penerapan health atau Kesehatan, sebagian pedagang yang berjualan di Wisata Kuliner Pasar Lama dapat memahami, menyatakan pengetahuannya serta menjalankannya mengenai penerapan safety atau keselamatan.para pedagang yang berjualan di Wisata Kuliner Pasar Lama dapat memahami, menyatakan pengetahuannya serta menjalankannya mengenai penerapan Environmental sustainability atau kelestarian lingkunga, sosialisasi tentang CHSE belum dilakukan secara menyeluruh, berdasarkan hasil wawancara sebagian Narasumber belum mendapat sosialisasi mengenai penerapan CHSE.
\end{abstract}

\section{ARTICLE HISTORY}

Submitted:04.11.2021

Revised:29.12.2021

Accepted:03.01.2022

Online first:05.01.2022

\section{KATA KUNCI}

Wisata kuliner, Cleanliness, Health, Safety, Environmental Sustainability 


\section{Pendahuluan}

Pertumbuhan sektor industri makanan dan minuman atau food $\mathcal{E}$ beverage di Indonesia tergolong cukup tinggi, hal ini didukung oleh tingkat konsumsi yang juga ikut meningkat oleh karena kebutuhan dasar akan makanan dan minuman keseharian manusia serta tersedianya keragaman makanan dan minuman yang menarik, selain itu penyebaran informasi mengenai makanan kian jelas oleh pergerakan besar teknologi informasi dan komunikasi yang telah digunakan oleh sebagian besar orang dengan adanya food blogger dan website mengulas makanan dan minuman. Sehingga, industri rumah makan terlihat berpeluang untuk terus berkembang guna memperoleh keuntungan di tengah peningkatan minat konsumen makanan dan minuman.

Rumah makan merupakan tempat yang menyediakan layanan makan dan minum, sebagai penyedia layanan rumah makan tentu menjadi penyedia lapangan pekerjaan yang luas. Oleh karena itu, rumah makan dalam industri makanan dan minuman menjadi sektor yang potensial untuk dikembangkan sebagai salah satu sumber pendapatan dan penggunaan sumber daya yang dapat menjadi pemasok bagi pembangunan ekonomi negara. Namun dengan adanya kondisi penyebaran virus Covid-19 yang terjadi saat ini, memberikan dampak bagi semua aspek pada ruang lingkup industri makanan dan minuman, baik dari pelaku usaha, pekerja, hingga konsumen. Hal ini terbukti dengan adanya pernyataan resmi oleh lembaga kesehatan dunia, World Health Organization (WHO) sebagai wabah yang mendunia pada tanggal 11 Maret 2020 dan diputuskan sebagai bencana nasional oleh Keputusan Presiden (Keppres) Republik Indonesia nomor 12 Tahun 2020 pada tanggal 13 april 2021. Hal tersebut menyebabkan para calon konsumen rumah makan dihadapkan dengan rasa khawatir akan terpaparnya virus, sehingga sektor usaha pariwisata Indonesia yang juga menanggung pergerakkan industri makan dan minuman perlu menyadari bahwa daya minat seseorang untuk melakukan kegiatan pembelian atas usaha pariwisata juga semakin rendah. Keadaan tersebut ditambah dengan tidak adanya peraturan khusus yang menjadi panduan standar bagi pelaku usaha dan pekerja dalam kondisi pandemi. Hal ini mendorong Kementerian Pariwisata dan Ekonomi Kreatif merancang kebijakan yang menjadi panduan bagi pelaku usaha dan pekerja pariwisata, yang diharapkan dapat memberikan kesan aman bagi para konsumen dengan protokol, sanitasi dan prosedur yang menjanjikan. 
Keputusan Menteri Pariwisata dan Ekonomi Kreatif Nomor KM/704/PL.07.02/M-K/2020 Tentang Petunjuk Teknis Hibah Pariwisata Dalam Rangka Pemulihan Ekonomi Nasional Tahun Anggaran 2020 diselenggarakan bersamaan dengan lahirnya kebijakan dan pembiayaan program verifikasi dan pemberian sertifikat Cleanliness, Health, Safety, and Environmental Sustainability (CHSE) pada industri hotel, restoran dan usaha kreatif dalam ruang lingkup pariwisata dan disahkan oleh Menteri Pariwisata dan Ekonomi Kreatif Republik Indonesia, Wishnutama Kusubandio. Kegiatan verifikasi dan perolehan sertifikat Cleanliness, Health, Safety, and Environmental Sustainability ini diharapkan dapat mengembalikan rasa percaya dan menumbuhkan minat berwisata para calon wisatawan sehingga terciptanya pergerakan pariwisata dan pemulihan ekonomi negara.

Kebijakan Cleanliness, Health, Safety, dan Environment Sustainability dilaksanakan bagi setiap pihak yang berperan didalamnya termasuk bidang restoran/rumah makan, yaitu pengusaha dan/atau pengelola restoran, karyawan restoran, dan tamu restoran. Kebijakan ini membahas panduan pada lingkup kebersihan, kesehatan, keselamatan dan kelestarian lingkungan. Panduan pelaksanaan tersebut juga dibagi berdasarkan panduan umum dan khusus. Pada panduan umum di rumah makan kebijakan ini mengatur dua aspek, Manajemen/Tata Kelola, sedangkan pada panduan khusus mengatur pihak yang berkepentingan di dalam rumah makan berdasarkan alur pelayanan rumah makan, hal ini berupa panduan pada pengusaha dan/atau pengelola rumah makan, karyawan rumah makan, dan tamu rumah makan pada beberapa alur pelayanan rumah makan, diantaranya area pintu masuk, pelayanan makan dan minum, pembayaran dan pintu keluar, dapur, ruang administrasi, dan ruang karyawan (ruang ganti dan ruang makan).

Kebijakan Cleanliness, Health, Safety, dan Environmental Sustainability (CHSE) ini dibagi berdasarkan panduan umum dan khusus yang menjadi syarat pengaplikasian pada rumah makan yang kemudian dilanjutkan dengan uji verifikasi oleh Kementerian Pariwisata dan Ekonomi Kreatif dan Lembaga Sertifikasi dari Indonesia Sustainable Tourism Certification (ISTC) baik oleh Global Sustainable Tourism Council (GSTC) atau Komite Akreditasi Nasional (KAN) untuk memperoleh legalitas rumah makan dapat beroperasi selama kondisi pandemi dengan adanya bukti labelling/sertifikasi. Adapun tujuan dari penelitian ini adalah untuk menganalisis penerapan cleanliness, health, safety dan environmental sustainability di Kawasan Wisata Kuliner Pasar Lama Tangerang. 


\section{Kajian Teori}

Wisata kuliner menurut Fadiati dalam Nugraha dan Sumardi (2019) adalah suatu kegiatan wisatawan mencari makan dan minum yang unik dan mengesankan. Menurut Hall dalam Nugraha dan Sumardi (2019) Wisata kuliner adalah kegiatan kunjungan seseorang ke tempat yang menghasilkan suatu makanan seperti festival makanan, restoran lokal, pasar, dan lokasi khusus, dengan tujuan untuk mencoba rasa makanan dan memperoleh pengalaman dari makanan khas suatu daerah. Menurut Ardika (2011) wisata kuliner adalah kegiatan untuk mencari makanan dan minuman unik serta mengesankan. Sehingga kegiatan wisata kuliner merupakan kegiatan yang tidak hanya berdasarkan keinginan untuk mencicipi rasa dari makanan tersebut, melainkan untuk memperoleh kenangan dan keunikan yang didapatkan setelah merasakan makanan tersebut.

Wisata kuliner merupakan bentuk pariwisata yang secara signifikan menekankan hubungan antara host and guest melalui makanan dan minuman sebagai budaya. Secara definitif (Horng \& Tsai, 2010) mengklaim bahwa pariwisata kuliner adalah pengalaman berwisata dengan aktivitas yang terkait makanan dan minuman, di mana pembelajaran budaya dan transfer pengetahuan dari destinasi dan masyarakatnya difasilitasi. Selain itu wisata kuliner menurut Kemenparekraf didefinisikan sebagai kegiatan wisata yang memungkinkan wisatawan untuk membayar dan menikmati makanan dan minuman, melakukan observasi terhadap proses produksi makanan/belanja (dari hulu ke hilir), serta menjadikan hal ini sebagai aktivitas perjalanan wisata yang paling penting dalam rangka menghasilkan pengalaman berwisata (Palupi \& Fitri, 2019).

Kebijakan CHSE merupakan kepanjangan dari Cleanliness, Health, Safety dan Environmental Sustainability atau Pelaksanaan Kebersihan, Kesehatan, Keselamatan, dan Kelestarian Lingkungan yang merupakan panduan operasional untuk sektor Pariwisata berdasarkan Keputusan Menteri Kesehatan Nomor HK.01.07/Menkes/382/2020 tentang Protokol Kesehatan bagi Masyarakat di Tempat dan Fasilitas Umum dalam Rangka Pencegahan dan Pengendalian Coronavirus Disease 2019 (Covid-19) (Kemenparekraf, 2020). Menurut Kemenparekraf (2020) Pada lingkup kebersihan yaitu, 1) Mencuci tangan pakai sabun/menggunakan hand sanitizer, 2) Ketersediaan sarana cuci tangan pakai sabun, 3) 
Edutourism Journal of Tourism Research I p-ISSN: 2686-4746 I e-ISSN: 2721-1371

Pembersihan ruang dan barang publik dengan cara dan desinfektan/cairan pembersih lain yang aman dan sesuai, 4) Bebas vektor dan binatang pembawa penyakit, 5) Pembersihan

dan kelengkapan toilet bersih, dan 6) Tempat sampah bersih. Menurut (Robert.H.Brook, 2017:585), kesehatan adalah sebuah sumber daya yang dimiliki semua manusia dan bukan merupakan suatu tujuan hidup yang perlu dicapai. Kesehatan tidak terfokus kepada fisik yang bugar tetapi meliputi jiwa yang sehat di mana individu dapat bersikap toleran dan dapat menerima perbedaan. Selain itu, pada lingkup kesehatan atau health menurut Kemenparekraf (2020) 1) Menghindari kontak fisik, pengaturan jarak aman, mencegah kerumunan, 2) Tidak menyentuh bagian wajah, terutama mata, hidung, mulut, 3) Pemeriksaan suhu tubuh, 4) Memakai APD yang diperlukan, 5) Menerapkan etika batuk dan bersin, pengelolaan makanan dan minuman yang bersih dan higienis, 6) Peralatan dan perlengkapan kesehatan sederhana, 7) Ruang publik dan ruang kerja dengan sirkulasi udara yang baik, serta 8) Penanganan bagi pengunjung dengan gangguan kesehatan ketika beraktivitas di lokasi. Lingkup keselamatan memuat panduan diantaranya, 1) Prosedur penyelamatan diri dari bencana, 2) Ketersediaan kotak P3K, 3) Ketersediaan alat pemadam kebakaran, 4) Ketersediaan titik kumpul dan jalur evakuasi, 5) Memastikan alat elektronik dalam kondisi mati ketika meninggalkan ruangan, 6) Media dan mekanisme komunikasi penanganan kondisi darurat (Kemenparekraf, 2020). Panduan pada lingkup pelestarian lingkungan memuat, 1) Penggunaan perlengkapan dan bahan yang ramah lingkungan, 2) Pemanfaatan air dan sumber energi secara efisien dan sehat dalam rangka menjaga keseimbangan ekosistem, 3) Pengolahan sampah dan limbah cair dilakukan secara tuntas, sehat, dan ramah lingkungan, 4) Kondisi lingkungan sekitar asri dan nyaman, baik secara alami atau dengan rekayasa teknis, 5) Pemantauan dan evaluasi penerapan panduan dan SOP Pelaksanaan Kebersihan, Kesehatan, Keselamatan, dan Kelestarian Lingkungan (Kemenparekraf, 2020).

Sertifikasi CHSE (Cleanliness, Health, Safety dan Environmental Sustainability) adalah proses pemberian sertifikat kepada usaha pariwisata, destinasi pariwisata, dan produk pariwisata lainnya untuk memberikan jaminan kepada wisatawan terhadap pelaksanaan kebersihan, kesehatan, keselamatan, dan kelestarian lingkungan (Kemenparekraf, 2020). Proses yang dilakukan untuk memperoleh sertifikat Cleanliness, Health, Safety dan Environmental Sustainability adalah sebagai berikut (Kemenparekraf, 2020): 
1. Penyusunan

Proses penyusunan merupakan proses pertama yang dilakukan untuk memenuhi persyaratan untuk perolehan sertifikat, proses ini merupakan bentuk kolaborasi stakeholders industri, pelaku, pemerintah, dan akademisi, untuk memperoleh:

a. Protokol kesehatan

b. Panduan pelaksanaan Cleanliness, Health, Safety dan Environmental Sustainability

2. Implementasi

Proses implementasi merupakan sosialisasi, edukasi, simulasi, dan uji coba pada:
a. Usaha pariwisata
b. Usaha Ekonomi Kreatif
c. Daerah
d. Destinasi
e. Panduan CHSE
3. Pemantauan

Proses pemantauan dibagi menjadi dua, verifikasi dan labelling/sertifikasi. Kegiatan ini dilakukan sebagai berikut:

1) Verifikasi

Dilakukan oleh Kementerian pariwisata dan ekonomi kreatif bersamaaan dengan lembaga sertifikasi ISTC (GSTC/KAN), yang ditugaskan sebagai berikut:

\section{A. Kemenparekraf}

- $\quad$ Tim terpadu nasional: kemenparekraf, kemenkes, asosiasi (PHRI, ASITA, GPI) yang bertugas menjadi verifikasi standar Cleanliness, Health, Safety dan Environmental Sustainability \& Deklarasi Mandiri kepada

- $\quad$ Tim provinsi: verifikasi (jenis usaha/sektor/fasilitas dan layanan publik) dan deklarasi mandiri wilayah provinsi

- $\quad$ Tim kabupaten/kota: verifikasi (jenis usaha/sektor/fasilitas dan layanan publik) dan deklarasi mandiri wilayah kab/kota

B. Lembaga Sertifikasi ISTC (GSTC/KAN)

- $\quad$ Standar/indikator, quality manual CHSE 
- Verificator/assessor/auditor

- Business process verification/assessment/sertifikasi

2) Labelling/sertifikasi

Proses labelling/sertifikasi dilakukan dengan:

- $\quad$ Pelaksanaan assessment

- Verification Dokumen/standar \& lapangan

- Tujuan: Recognition, Confidence/ Credibility, Calibration

- $\quad$ Logo/labelling “InDOnesiaCARE” certified

- Durasi 1 tahun

- $\quad$ Midterm review, audit /control

- $\quad$ Insentif dan Skema Dukungan untuk Usaha Parekraf

- $\quad$ Pendampingan/Advocacy

\section{Metode Penelitian}

Jenis penelitian yang tim peneliti gunakan dalam penelitian ini adalah penelitian deskriptif kualitatif. Menurut Bogdan dan Taylor "metode kualitatif" sebagai prosedur penelitian yang menghadirkan data deskriptif beberapa kata kata tertulis atau lisan dari orang-orang atau pelaku yang dapat diamati (Moleong, 2018). Metode penelitian kualitatif biasanya mencakup wawancara dan observasi, tetapi mungkin juga termasuk studi kasus, survei, dan analisis historis dan dokumen. Penelitian deskriptif kualitatif bertujuan untuk menggambarkan, melukiskan, menerangkan,menjelaskan dan menjawab secara lebih rinci permasalahan yang akan diteliti dengan mempelajari semaksimal mungkin seorang individu, suatu kelompok atau suatu kejadian (Mulyana, 2014) . Penelitian ini memiliki tujuan untuk mendapatkan informasi dan gambaran mengenai penerapan cleanliness, health, safety, dan environment sustainability yang dilakukan di Kawasan Wisata Kuliner Pasar Lama dengan lebih jelas dan lugas. Sehingga tim peneliti akan melakukan sebuah wawancara dengan para pedagang yang berjualan yang berada di Kawasan Wisata Kuliner Pasar Lama yang memahami tentang penerapan cleanliness, health, safety, dan environment sustainability di Kawasan Wisata Kuliner Pasar Lama. Wawancara dan observasi ini akan tim peneliti lakukan secara langsung yaitu datang ke Kawasan Wisata Kuliner Pasar Lama.

Sumber data memiliki peran yang sangat penting dalam sebuah penelitian, dengan adanya 
Edutourism Journal of Tourism Research I p-ISSN: 2686-4746 I e-ISSN: 2721-1371

sumber data dapat memudahkan proses penelitian. Sumber data terdiri dari data dan tindakan,sumber data tertulis, foto, dan statistik. Sumber data yang Tim peneliti gunakan adalah sumber data primer dan sumber data sekunder. Sumber data primer yaitu

sumber data yang diambil peneliti melalui wawancara dan observasi. Data primer adalah data yang diperoleh atau dikumpulkan langsung di lapangan oleh orang yang melakukan penelitian atau yang bersangkutan yang memerlukannya. Data primer ini disebut juga data asli atau data baru. Sumber data tambahan yaitu sumber data di luar kata-kata dan tindakan yakni sumber data tertulis. Data sekunder adalah data yang diperoleh atau dikumpulkan oleh orang yang melakukan penelitian dari sumber-sumber yang telah ada. Data ini seharusnya atau biasanya diperoleh dari perpustakaan atau dari laporan-laporan penelitian terdahulu.

Teknik pengumpulan data merupakan cara yang efisien dalam sebuah penelitian, karena tujuannya sendiri untuk mendapatkan/ mengumpulkan data. Tanpa mengetahui teknik pengumpulan data, maka tim peneliti akan kesulitan mendapatkan data yang memenuhi standar data yang ditetapkan. Teknik pengumpulan data dapat dilakukan dengan cara, observasi, wawancara, dan dokumentasi. Namun dalam penelitian ini, tim peneliti hanya menggunakan 3 teknik pengumpulan data yaitu: 1) Wawancara : Menurut Sugiyono (2016), wawancara merupakan pertemuan dua orang untuk bertukar informasi dan ide melalui tanya jawab, sehingga dapat dikonstruksikan makna dalam suatu topik tertentu. Dalam teknik wawancara ini, peneliti melakukan tanya jawab kepada pedagang yang berjualan di Kawasan Wisata Kuliner Pasar Lama secara tatap muka. Melalui wawancara ini, peneliti akan mengetahui lebih dalam mengenai penerapan Clean, Health, Safety \& Environmental pada restoran. Susan Stainback mengemukakan bahwa dengan wawancara, maka peneliti akan mengetahui hal-hal yang lebih mendalam tentang partisipan dalam menginterpretasikan situasi dan fenomena yang terjadi, dimana hal ini tidak dapat ditemukan melalui observasi (Sugiyono 2016). 2) Menurut Sugiyono, Observasi merupakan teknik pengolahan data yang mempunyai ciri yang spesifik bila dibandingkan dengan teknik yang lain. Menurut Marshall menyatakan bahwa, "through observation, the researcher learn behavior and the meaning attached to those behavior" (Sugiyono, 2016). Melalui observasi, peneliti belajar tentang perilaku, dan makna dari perilaku tersebut. Dalam melakukan observasi, peneliti akan terlibat kegiatan sehari-hari proses kerja dan orang yang diamati sebagai sumber data penelitian. Dalam hal ini observasi dilakukan dengan mengamati secara langsung tentang 
Edutourism Journal of Tourism Research I p-ISSN: 2686-4746 I e-ISSN: 2721-1371

penerapan Cleanliness, Health, Safety, and Environmental Sustainability di Kawasan Wisata

Kuliner Pasar Lama.

Analisis data dilakukan dengan wawancara bersama pedagang yang ada Kawasan Wisata Kuliner Pasar Lama. Setelahnya peneliti mengolah data dari hasil data yang didapatkan melalui rekaman wawancara tersebut dan menyalinnya dalam bentuk tulisan berdasarkan konteks data yang diperlukan. Metode yang tim peneliti gunakan dalam menganalisis data pada penelitian ini adalah analisis interaktif. Beberapa tahapan model analisis interaktif Miles dan Herberman melalui empat tahap, yakni pengumpulan data, reduksi data, penyajian data dan penarikan kesimpulan.

\section{Hasil dan Pembahasan}

Kegiatan wawancara dilakukan oleh tim peneliti dengan memberikan pertanyaanpertanyaan mengenai Cleanliness, Health, Safety and Environmental sustainability (CHSE) pada Kawasan Wisata Kuliner Pasar Lama. Sehingga tim peneliti akan menanyakan dua topik dengan delapan pertanyaan akan pengetahuan narasumber mengenai penerapan Cleanliness, Health, Safety and Environmental sustainability, serta konsep dalam penerapan Cleanliness, Health, Safety and Environmental sustainability selama berjualan produk kuliner tersebut di Kawasan Wisata Kuliner Pasar Lama.

Pada pertanyaan pertama topik pertama tim peneliti menanyakan pengetahuan pedagang mengenai penerapan cleanliness atau kebersihan. Pada pedagang yang pertama menjelaskan kebersihan menurutnya adalah hal yang telah pelajarinya dari dahulu di sekolah yang mencakup segala sesuatu, mulai dari tempat yang hygiene, lalu dari pegawainya, hingga untuk bahan makanan yang fresh. Sedangkan kebersihan menurut pedagang kedua adalah memasak dengan bersih, jika terdapat kotoran langsung segera dibersihkan. Pada pedagang ketiga menjelaskan bahwa kebersihan itu merupakan HACCP dengan training untuk standarisasi clean as you go, baik dari awal hingga akhir kegiatan berjualan harus tetap bersih, baik selama operasional customer pulang dan pergi dengan memastikan peralatan dalam keadaan bersih. Namun pada penjelasan pengetahuan pedagang keempat dipaparkan bahwa kebersihan yang menyangkut semua hal selama berjualan yaitu harus dalam keadaan bersih dari sampah dengan menampungnya. Atas penjelasan tiap pedagang mengenai pengetahuannya mengenai penerapan cleanliness atau kebersihan telah diketahui pada 
Edutourism Journal of Tourism Research | p-ISSN: 2686-4746 I e-ISSN: 2721-1371

mereka masing-masing yang dijelaskan dengan berfokus pada produk yang dijual, pekerja, peralatan serta kondisi sekitar area berjualan yang mencontohkan kegiatannya selama berjualan.

Pada pertanyaan kedua tim peneliti mengajukkan pertanyaan mengenai pengetahuan pedagang tentang penerapan health atau kesehatan. Pada pedagang pertama, ia memaparkan bahwa kesehatan berasal dari pegawai, mengingat sedang dalam kondisi pandemi covid-19 untuk adanya pengecekan kesehatan rutin antara PCR ataupun Antigen, dan menitikkan kepentingan bahwa pegawai telah vaksin. Selain itu pedagang pertama memaparkan juga bahwa kesehatan juga berasal dari makanan untuk mengusahakan adonan yang telah dikeluarkan akan habis dan tidak menyimpannya. Sedangkan menurut pedagang kedua kesehatan merupakan mengimplementasikan protokol kesehatan yang merupakan anjuran pemerintah dengan penggunaan masker, jaga jarak, serta dengan mencuci tangan. Namun menurut pedagang ketiga keselamatan adalah diawali dengan personalnya atau man powernya dipastikan untuk sehat dengan pengecekkan kesehatan rapid dalam kondisi fit, juga dengan berpakaian dan grooming yang dapat dilihat bersih. Meskipun begitu menurut pedagang keempat kesehatan merupakan dengan menggunakan masker, menjaga jarak dan mematuhi protokol pemerintah serta menegaskan bahwa ia telah melakukan vaksinasi. Berlandaskan pada pernyataan masing-masing pedagang mengenai pengetahuan mereka tentang penerapan kesehatan, setiap pedagang menyetujui untuk fokus pada dirinya sendiri atau pekerja selama berjualan mengingat dengan kondisi pandemi dengan patuh pada protokol kesehatan atas anjuran pemerintah.

Pada pertanyaan ketiga topik pertama juga ditanyakan oleh peneliti mengenai pengetahuan pedagang akan penerapan safety atau keselamatan. Pedagang pertama menjawab bahwa safety bergantung pada diri pegawainya untuk aware pada keselamatan dengan menjaga kesehatan dan mengantisipasi jarak dengan mesin api, panas dan dengan pisau. Sedangkan pedagang kedua menjelaskan bahwa ia sempat bingung akan keselamatan selama berjualan, pedagang kedua mengira bahwa peralatan keselamatan hanya digunakan pada kegiatan beresiko tinggi seperti pekerja tambang, namun ia menegaskan kemungkinan bentuk safety diimplementasikan dengan pakaian rapi dan sopan. Pada pemaparan pengetahuan pedagang ketiga menjelaskan bahwa tidak menggunakan peralatan yang berat 
Edutourism Journal of Tourism Research I p-ISSN: 2686-4746 | e-ISSN: 2721-1371

dan jika terkena benda tajam sudah dipersiapkan kotak P3K sebagai penanganan pertama.

Selanjutnya menurut pedagang keempat dijelaskan bahwa keselamatan merupakan dengan tetap berhati-hati selama bekerja seperti selama mendorong gerobak harus dengan pelan dan hati-hati. Berdasarkan pernyataan dari keempat pedagang atas jawaban pertanyaan pengetahuan penerapan safety atau

keselamatan adalah telah memahami pengertian dari masing-masing pedagang, pemaparannya mengenai keselamatan pada pekerja berupa pakaiannya, penggunaan peralatan hingga perlengkapan berjualan.

Pada topik pertama pertanyaan keempat, tim peneliti menanyakan tentang pengetahuan pedagang mengenai penerapan environmental sustainability atau kelestarian lingkungan. Jawaban yang disampaikan pedagang pertama adalah dengan membuang sampah tidak sembarangan. Pada pedagang kedua menjelaskan bahwa pengetahuannya soal kelestarian lingkungan hanya dengan berfokus pada sampah yang ditampung di tempatnya sehingga tidak berserakkan. Sedangkan pada pedagang ketiga menjelaskan bahwa kelestarian lingkungan biasanya diterapkan pada pedagang yang telah bertahan lebih dari 10 tahun karena telah memiliki customer loyal pada mereka dan penerapan kelestarian lingkungan juga merupakan kemajuan dari perusahaan itu. Sedangkan pada pedagang keempat kelestarian lingkungan adalah berupa kegiatan menanam pohon ataupun penghijauan. Berdasarkan jawaban dari keempat pedagang mengenai pengetahuannya masing-masing akan penerapan environmental sustainability atau kelestarian lingkungan yang telah disampaikan dianggap telah memahami dengan penjelasannya yang juga berupa perwujudan environmental sustainability atau kelestarian lingkungan itu dengan pengelolaan sampah maupun penggunaan perlengkapan produk kuliner selama berjualan di Kawasan Wisata Kuliner Pasar Lama.

Pada pertanyaan pertama topik kedua tim peneliti menanyakan kepada pedagang mengenai konsep penerapan cleanliness atau kebersihan yang pedagang tersebut telah lakukan selama berjualan di Kawasan Wisata Kuliner Pasar Lama. Pedagang pertama memaparkan bahwa konsep penerapan kebersihan yang ia lakukan selama berjualan adalah dengan semaksimal mungkin menjaga kebersihan dari awal hari dengan menyapu, mengepel, dan lainnya. Mengusahakan untuk membersihkan peralatan berjualan seperti pemanggang sehingga customer dapat melihat tempat yang bersih. Sedangkan pada 
Edutourism Journal of Tourism Research I p-ISSN: 2686-4746 | e-ISSN: 2721-1371

pedagang kedua konsep penerapan kebersihan selama berjualan dilakukan dengan menghindarkan barang jualnya dari serangga seperti lalat dengan menutup bahan-bahan makanan dan peralatan, selain itu pedagang kedua juga mengakui bahwa setiap terdapat pesanan akan menggunakan peralatan yang bersih, serta membersihkan pada saat buka dan tutup. Berdasarkan observasi yang tim peneliti lakukan hal ini benar terbukti dengan pemasangan tirai di gerobak dan penggunaan wadah tertutup pada setiap bahan

makanannya, selain itu peralatan seperti ulekan kami melihatnya dengan keadaan bersih. Pada pedagang yang ketiga konsep penerapan kebersihannya adalah dengan staff yang datang segera melakukan pembersihan dirinya terlebih dahulu, selanjutnya tersedianya hand sanitizer, menghindari kontak fisik, serta jika terdapat pesanan take away menggunakan label segel sehingga produk yang sampai ke customer tetap dalam keadaan bersih, serta penerapan clean as you go yang utama. Berikutnya pada pedagang keempat akan jawaban yang diberikan berkaitan dengan konsep penerapan kesehatan selama berjualan adalah dengan tetap menjaga lingkungan sekitar agar tetap bersih dengan mencuci gelas setelah pemakaian, menyapu tempat berjualan, serta menyiapkan tempat sampah. Pernyataan tersebut benar dilakukan oleh pedagang keempat karena tim peneliti melihat pada saat itu gelas yang telah digunakan langsung dicuci dan dikeringkan pada waktu yang berdekatan. Berdasarkan penjelasan para pedagang mengenai konsep penerapan cleanliness atau kebersihan yang masing-masing memberikan pernyataan atas perwujudan yang berbeda yaitu berfokus pada kebersihan di lokasi tempat berjualan, kualitas bahan dan alat selama berjualan, kondisi pekerja, serta memikirkan produk tersebut dapat bersih sampai pada konsumen.

Pada pertanyaan kedua topik kedua, pertanyaan yang disampaikan oleh tim peneliti pada pedagang mengenai konsep penerapan healthy atau kesehatan selama berjualan. Pedagang pertama menjelaskan bahwa konsep penerapan kesehatan selama berjualan dilakukan oleh setiap karyawan dengan menggunakan masker, sarung tangan untuk memegang peralatan selama membuat makanan sehingga tidak terkontaminasi dari tangan karyawan. Hal ini dilihat langsung oleh tim peneliti yaitu pekerja saat itu menggunakan masker dan tersedianya sarung tangan. Meskipun begitu menurut pedagang kedua konsep penerapan kesehatan selama berjualan adalah dengan fokus pada kesehatan pribadi yaitu menjalani protokol kesehatan dengan penggunaan masker, jaga jarak, dan mencuci tangan. Hal ini benar dilakukan oleh pedagang berdasarkan hasil observasi yaitu dengan memakai masker dan 
Edutourism Journal of Tourism Research | p-ISSN: 2686-4746 I e-ISSN: 2721-1371

menjaga jarak dengan pelanggan, sedangkan pada informasi cuci tangan tim peneliti tidak melihat tempat cuci tangan pada sekitar lokasi penjualan maupun kegiatan pedagang tersebut selama mencuci tangannya. Berikutnya konsep penerapan kesehatan oleh pedagang ketiga adalah dengan berfokus pada pekerja jika dalam keadaan sakit seperti flu dan lain-lain dapat diberikan izin untuk pulang. Meskipun begitu tim peneliti melihat bahwa penerapan kesehatan juga diwujudkan dengan pemakaian masker pada pegawainya.

Berikutnya pada penjelasan pedagang keempat mengenai konsep penerapan kesehatan selama berjualan adalah dengan menjaga kualitas bahan contohnya santan agar tetap layak dikonsumsi dan tidak membahayakan kesehatan konsumen. Berdasarkan pernyataan para pedagang mengenai konsep penerapan health atau kesehatan adalah memusatkan kesehatan dari penjual, bahan produk yang dijual, hingga konsumen.

Pertanyaan ketiga pada topik kedua merupakan pertanyaan berupa konsep penerapan safety atau keselamatan pedagang selama menjalankan aktivitas berjualannya. Jawaban yang disampaikan oleh pedagang pertama mengenai konsep penerapan keselamatan adalah berfokus pada karyawan masing-masing yang diusahakan untuk menggunakan sepatu yang aman jika terkena benda keras yang jatuh, sehingga tidak menyakiti karyawan tersebut. Selain itu penerapan dari keselamatan juga diwujudkan dengan melakukan penyimpanan benda-benda tajam dengan baik jika ingin digunakan dapat dengan mudah diambil. Selain itu perbedaan pada pedagang kedua dalam konsep penerapannya selama berjualan diakui bahwa tidak adanya barang yang membahayakan, jika tabung gas pengelolaannya adalah dengan dicabut jika tidak digunakan sehingga tidak akan membahayakan. Hal ini tidak nyata dilakukan pada saat tim peneliti melakukan observasi, dikarenakan terdapat pelanggan yang datang bergilir selama kegiatan wawancara berlangsung. Selain itu pernyataan yang ditunjukkan oleh pedagang ketiga mengenai konsep penerapan keselamatan adalah dengan menyediakan kotak Pertolongan Pertama Pada Kecelakaan (P3K) jika seandainya terdapat pekerja yang cedera dan lainnya dapat segera ditangani. Namun pada pernyataan pedagang keempat mengenai konsep penerapan keselamatan diwujudkan dengan perlunya kehatihatian selagi menggunakan benda tajam seperti pisau dan gunting. Hal ini benar diwujudkan dengan menaruh perlengkapan berjualan dengan hati-hati pada tempat khusus untuk menyimpan. Berdasarkan penjelasan para pedagang mengenai konsep penerapan safety atau keamanan diwujudkan dengan fokus pada perlengkapan dan peralatan selama berjualan, 
Edutourism Journal of Tourism Research I p-ISSN: 2686-4746 | e-ISSN: 2721-1371

keselamatan para pekerja dengan menggunakan pakaian yang aman serta menyiapkan pertolongan pertama pada kecelakaan.

Pada pertanyaan keempat topik kedua yang berupa pertanyaan pada pedagang yang disampaikan oleh tim peneliti mengenai konsep penerapan environmental sustainability atau kelestarian lingkungan yang dilakukan selama berjualan di Kawasan Wisata Kuliner Pasar Lama. Pada pemaparan pedagang pertama mengenai konsep penerapan kelestarian lingkungan diakui bahwa ia kurang mengetahuinya. Sedangkan jawaban pada pedagang

kedua adalah dengan pengumpulan sampah dengan baik ke tempatnya, perolehan dan pengelolaan air bersih juga dilakukan pada tempat bersih, dan jika kotor langsung dibuang pada saluran air terdekat sehingga tidak menggenangi lokasi sekitar. Hal ini terwujud dengan didapatinya galon air mineral sekitar lokasi berjualan, sedangkan pada pembuangan air kotor tidak dilakukan selama observasi oleh tim peneliti. Sedangkan pada pernyataan pedagang ketiga mengenai konsep penerapan kelestarian lingkungan selama berjualan adalah belum terlaksananya penerapan kelestarian lingkungan dan diperkirakan mungkin perlu beberapa tahun untuk mewujudkan penerapan tersebut. Hal ini benar dinyatakan karena selama observasi tim peneliti masih melihat penggunaan plastik pada kemasan dan sedotan untuk produk yang dijualkan. Kemudian pada pedagang keempat menjelaskan bahwa konsep penerapan kelestarian lingkungan diwujudkan hanya dengan fokus menyediakan tempat sampah yang baik. Berdasarkan masing-masing jawaban pedagang mengenai konsep penerapan environmental sustainability atau kelestarian lingkungan selama berjualan adalah sebagian besar berfokus pada pengendalian tempat sampah, dan masih terdapat pedagang yang belum memahami penerapan tersebut pada tokonya maupun belum melaksanakannya.

Berdasarkan data yang telah dikumpulkan dan disajikan, maka berikutnya peneliti melakukan pengolahan pada semua data yang telah terkumpul, data tersebut berdasarkan hasil wawancara dengan teori yang ada. Oleh karena itu tim peneliti dapat menggabungkan informasi terkait pengetahuan penerapan cleanliness, health, safety, and environmental sustainability dan konsep penerapan cleanliness, health, safety, and environmental sustainability di Kawasan Wisata Kuliner Pasar Lama.

Pengetahuan dan konsep penerapan cleanliness atau kebersihan pada pedagang pertama telah sesuai dengan pedoman lingkup kebersihan menurut Kemenparekraf (2020), pada nomor tiga yaitu pembersihan ruang dan barang publik dengan cara desinfektan/cairan 
Edutourism Journal of Tourism Research I p-ISSN: 2686-4746 I e-ISSN: 2721-1371

pembersih lain yang aman dan sesuai. Sedangkan pada pedagang kedua mengenai pengetahuan dan konsep penerapan kebersihan telah memenuhi hanya pada nomor tiga yaitu pembersihan ruang dan barang publik dengan cara desinfektan/cairan pembersih lain yang aman dan sesuai, empat yaitu bebas vektor dan binatang pembawa penyakit, dan enam yaitu tempat sampah bersih. Pada pedagang ketiga mengenai pengetahuan dan konsep penerapan kebersihan yang telah dijalankan selama berjualan adalah telah memenuhi aspek kebersihan nomor satu yaitu mencuci tangan pakai sabun/menggunakan

hand sanitizer, nomor tiga pembersihan ruang dan barang publik dengan cara dan desinfektan/cairan pembersih lain yang aman dan sesuai dan enam tempat sampah bersih. Selanjutnya pada pedagang yang keempat mengenai pengetahuan dan konsep penerapan kebersihan yang telah dijalankan telah sesuai dengan pedoman nomor tiga saja yaitu pembersihan ruang dan barang publik dengan cara dan desinfektan/cairan pembersih lain yang aman dan sesuai. Berdasarkan kesesuaian pengetahuan serta konsep penerapan cleanliness atau kebersihan sebagian besar hanya menerapkan pada komponen nomor tiga yaitu pembersihan ruang dan barang publik dengan cara dan desinfektan/cairan pembersih lain yang aman dan sesuai, dan nomor 6 yaitu tempat sampah bersih.

Pengetahuan dan konsep penerapan health atau kesehatan pada pedagang pertama sesuai dengan pedoman nomor empat yaitu memakai APD yang diperlukan, dan lima yaitu dengan menerapkan etika batuk dan bersin, pengelolaan makanan dan minuman yang bersih dan higienis. Selain itu berdasarkan pedagang kedua akan kesehatan telah memenuhi berdasarkan nomor satu yaitu menghindari kontak fisik, pengaturan jarak aman, mencegah kerumunan, dan empat yaitu memakai APD yang diperlukan. Pada pedagang yang ketiga pengetahuan dan konsep penerapan health atau kesehatan telah sesuai dengan nomor satu yaitu menghindari kontak fisik, pengaturan jarak aman, mencegah kerumunan, nomor empat yaitu memakai APD yang diperlukan, dan delapan yaitu penanganan bagi pengunjung dengan gangguan kesehatan ketika beraktivitas di lokasi. Sedangkan pada pedagang keempat mengenai pengetahuan dan konsep penerapan health atau kesehatan telah memenuhi hanya pada nomor empat yaitu memakai APD yang diperlukan. Berdasarkan kesesuaian pengetahuan serta konsep penerapan health atau kesehatan sebagian besar hanya menerapkan pada komponen nomor empat yaitu memakai APD yang diperlukan.

Pengetahuan dan konsep penerapan safety atau keselamatan pada pedagang pertama, 
Edutourism Journal of Tourism Research I p-ISSN: 2686-4746 I e-ISSN: 2721-1371

kedua, dan keempat tidak sesuai dengan pedoman lingkup safety atau keselamatan menurut Kemenparekraf (2020), dan berdasarkan pengetahuan dan konsep penerapan safety atau keselamatan pada pedagang ketiga telah sesuai dengan pedoman nomor dua yaitu ketersediaan kotak P3K. Oleh karena itu pada komponen safety atau keselamatan pengetahuan dan konsep penerapan pada sebagian besar pedagang di Kawasan Wisata Kuliner Pasar Lama belum terpenuhi. Pengetahuan dan konsep penerapan environmental sustainability atau kelestarian lingkungan pada pedagang pertama, ketiga, dan keempat

tidak sesuai dengan pedoman. Pada pedagang kedua telah sesuai dengan nomor dua yaitu pemanfaatan air dan sumber energi secara efisien dan sehat dalam rangka menjaga keseimbangan ekosistem, dan tiga yaitu pengolahan sampah dan limbah cair dilakukan secara tuntas, sehat, dan ramah lingkungan. Sehingga pengetahuan dan konsep penerapan environmental sustainability atau kelestarian lingkungan pada sebagian besar pedagang di Kawasan Wisata Kuliner Pasar Lama belum terlaksana.

\section{Kesimpulan}

Berdasarkan hasil penelitian dan pembahasan pada bab sebelumnya dapat ditarik beberapa kesimpulan guna menjawab rumusan masalah. Beberapa kesimpulan tersebut terdiri dari:

1. Sebagian besar pedagang yang berjualan di Wisata Kuliner Pasar Lama sudah memahami konsep dari penerapan CHSE yang dianjurkan pemerintah.

2. Para pedagang yang berjualan di Wisata Kuliner Pasar Lama dapat memahami, menyatakan pengetahuannya serta menjalankannya mengenai penerapan cleanliness atau kebersihan.

3. Para pedagang yang berjualan di Wisata Kuliner Pasar Lama dapat memahami, menyatakan pengetahuannya serta menjalankannya mengenai penerapan health atau kesehatan.

4. Sebagian pedagang yang berjualan di Wisata Kuliner Pasar Lama dapat memahami, menyatakan pengetahuannya serta menjalankannya mengenai penerapan safety atau keselamatan.

5. Para pedagang yang berjualan di Wisata Kuliner Pasar Lama dapat memahami, menyatakan pengetahuannya serta menjalankannya mengenai penerapan Environmental sustainability atau kelestarian lingkungan.

6. Sosialisasi tentang CHSE belum dilakukan secara menyeluruh, berdasarkan hasil wawancara sebagian Narasumber belum mendapat sosialisasi mengenai penerapan CHSE. 


\section{Author's declaration}

\section{Authors' contributions and responsibilities}

$\sqrt{ }$ The authors made substantial contributions to the conception and design of the study.

$\sqrt{ }$ The authors took responsibility for data analysis, interpretation and discussion of results.

$\sqrt{ }$ The authors read and approved the final manuscript.

\section{Availability of data and materials}

$\sqrt{ }$ All data are available from the authors.

\section{Competing interests}

$\sqrt{ }$ The authors declare no competing interest. 


\section{Referensi}

1) Ardika, I. W. (2011). Gastronomi dalam Pariwisata Budaya. Pemberdayaan dan Hiperdemokrasi dalam Pembangunan Pariwisata. Persembahan untuk Prof. Ida Bagus Adnyana Manuaba. Denpasar: Pustaka Larasan.

2) Kemenparekraf. (2020). Panduan Pelaksanaan Kebersihan, Kesehatan, Keselamatan dan Kelestarian Lingkungan di Restoran / Rumah Makan. 2019,57. https://chse.kemenparekraf.go.id/storage/app/media/dokumen/Pedoman Restoran.pdf

3) Kemenparekraf. (2020). Model dan Proses Verifikasi, Sertifikasi CHSE. Journal of Chemical Information and Modeling, 53(9), 1689-1699.

4) Kemenparekraf. (2020). Syarat \& Ketentuan CHSE Kemenparekraf. Chse.Kemenparekrafn.Go.Id. https://chse.kemenparekraf.go.id/syarat-ketentuan\#07

5) Kemenparekraf, I. (2013). Peraturan Menteri Pariwisata and Ekonomi Kreatif No. 53 tahun 2013. Peraturan Menteri Pariwisata Dan Ekonomi Kreatif Republik Indonesia, 227.

6) Moleong, L. J. (2018). Metodologi penelitian kualitatif / penulis, Prof. DR. Lexy J. Moleong, M.A. (edisi revisi). PT Remaja Rosdakarya.

7) Nugraha, S., \& Sumardi, S. (2019). Destinasi Wisata Kuliner Berbasis Makanan Tradisional di Kabupaten Toba Samosir. Jurnal Akademi Pariwisata Medan, 7(2), 33-46.

8) Palupi, S., \& Fitri, A. (2019). Pendoman Pengembangan Wisata Kuliner. Deputi Bidang Pengembangan Industri Dan Kelembagaan Kementerian Pariwisata, 83. https://disbudparpora.ponorogo.go.id/wisata-kuliner/

9) Sugiyono (2016). Metode Penelitian Kuantitatif, Kualitatif, R\&D. Bandung:IKAPI

10) Simanjuntak, J. H. H. (2020). Pendekatan teori antrean menggunakan metode M / M / 1 ( Studi Kasus Sate Taichan Goreng Summarecon, Bekasi Barat ). Jurnal STEI Ekonomi, $\mathrm{XX}(\mathrm{Xx}), 1-28$. 